\title{
The Effect of Anonymity on Twitter towards its Users Based on Derek Parfit's Personal Identity Theory
}

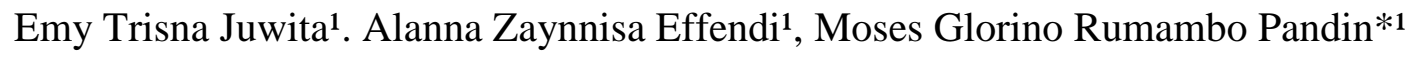 \\ ${ }^{1}$ Fakultas Ilmu Budaya, Universitas Airlangga, Surabaya, Indonesia
}

\author{
*Corresponding Author E-Mail: moses.glorino@ fib.unair.ac.id \\ Faculty of Humanities, Universitas Airlangga \\ J1. Dharmawangsa Dalam Selatan, Kampus B, Surabaya, 60286
}

\begin{abstract}
Twitter is one of the most accessed social media, especially by teenagers, with a high rate of anonymity. This phenomenon raises questions regarding whether any effects arise from the usage of anonymous accounts. This study aims to find out the impact of using an anonymous Twitter account on its users from the perspective of Derek Parfit's self-identity theory. The research method used is a mixture of quantitative and qualitative. Quantitative data is obtained through surveys and qualitative through interviews. The survey was conducted online on a population of 50 teenagers, with the sample criteria being at least 18 years old and being an anonymous account user on Twitter. The sampling was taken randomly from the population. The interview method was carried out on the same people and sample with a smaller quantity to strengthen the survey data. The results show that using Twitter anonymously is directly proportional to being more open (oversharing). The results of this study are in accordance with Derek Parfit's self-identity theory which believes that a person will tend to be more forthcoming if they do not know each other's identity. With the finding that using anonymous accounts seems to provide an incentive to express themselves more freely, it is hoped that this research can be a source of additional studies and create a more reflective attitude for all social media users in general. This study is limited to anonymous users of social media Twitter in the adolescent age range.
\end{abstract}

Keywords: influence, anonymity, Twitter, self-identity, Derek Parfit

\section{INTRODUCTION}

Before becoming an important part of life, the internet was once only used in the United States in the 1990s-2000s. Afterward, in 2016, more than 50\% of United States' citizens reported having access to the internet. Later, the growth is followed by countries in other parts of the world, such as Iceland, Denmark, Norway, Japan, and Malaysia (Roser et al., 2015). In 
years, increasing internet usage has occurred in an expeditiously way. Nowadays, people worldwide can access the internet easily. International Telecommunication Union (ITU) reported that in 2018 the internet user reached 3.9 million in the world or exceeded half of the overall human population on Earth.

Most internet users are aged 24-35, 35-44, and adolescents range from 18-24 (Johnson, 2021). In early January of 2021, there was a report that not less than 4.66 million people used the internet worldwide. This number of users has increased 316 million or $7.3 \%$ since 2020 . Meanwhile, there were 4.20 million active users for social media users globally. This number also undergoes an increased trend of 490 million in 12 months (Kemp, 2021). With this massive number of users, it can be said that the active users of social media exceeded $53 \%$ of the human population in total.

According to Statistica (2021), the most use of social media is Facebook with 2,895 million active users, Youtube with 2,291 million users, Instagram with 1,393 million users, and Twitter with 463 million active users. Most of those social media can be accessed by those aged 13 in minimum. However, that thing is considered ineffective because of the low regulation of creating new accounts for new users. As a result, the rules can still be tricked by data forgery. That action is most likely causing underage users can access the applications freely, unsupervised.

Children to early adolescents are parties with a high possibility of doing absorptive behavior uncontrollably. They imitate what they get without ideally filtering which one is good or bad. The growth of mentality and emotion that is still unstable can cause adolescents to get many psychological problems, such as depression, inferiority, and eating disorder (Nesi, 2020). They are prone to fall, whether as victims or bullies of cyberbullying. Simsek (2019), in her research, showed that adolescents who use the internet without proper supervision have a 
higher risk of being plunged into cyberbullying than those who use the internet under supervision. Social media give space with no limit to its users to share and post anything. Even though some regulations have been made to minimize the infringement rate, the problem still cannot be cured entirely.

\section{The effects of anonymity on Twitter}

As a social media that teenagers favor, Twitter offers unlimited convenience and freedom. Unlike Facebook and Instagram, Twitter users can make them accepted even when they are anonymous. Twitter gives freedom to its users to make accounts anonymously. A survey was conducted in 2017 by an online site by capturing random 2010 Twitter accounts as a sample. The result showed that $6 \%$ of the sampling accounts are anonymous. $20 \%$ is a semianonymous account because it still has and encloses names on their accounts. The rest of the $68 \%$ of the sample can not be identified because it is highly possible to use fake identity, while $6 \%$ do not pass the classification. The high rate of anonymity on Twitter is related to the freedom of reaching out to sensitive issues. A survey by InfoQ stated that most of the sensitive issues were followed and accessed by many anonymous accounts. An amount of $21.6 \%$ of the sample follows pornography content and other sensitive topics.

This high anonymity rate makes Twitter users feel free to share what they want. Twitter users can still be well accepted without revealing their background and identity. The most visible effect of this phenomenon is the emergence of a tendency to create new personalities that may be completely different from their original personalities in the real world. These personalities were built unconsciously by considering three main points: individual orientation, personal values, and self-appreciation (Ayun, 2015).

Based on Ayun's (2015) research, Twitter users' purpose in building new personalities is to convince others that they are kind-hearted, calm, and easy-going people. Some Twitter 
users assume Twitter as a safe platform to run away from compared to other social media, so they avoid showing off their true identity and personality. It aims to avoid knowing their existence on Twitter by people who know them directly in the real world.

\section{Social Media Twitter}

Twitter first launched in 2006 and was categorized as the most used application in 2021 (Wagner, 2021). Twitter serves numerous features, such as direct message, posting a tweet, video, picture, interaction, and sharing something by retweet feature. The number of characters that can be written down is limited to 280 characters. Nevertheless, Twitter provides thread features or a feature where people can tweet sustainably. It seemed to be a practical feature and fun because even though the amount of character on each post is limited, the users can still share long tweets sequentially.

In 2021, Twitter users are dominated by the age range 25-34, followed by age range 35-49, age-range 18-24, and range more than 50 years old have the same presentation, which is $17.1 \%$ and followed by age range $13-17$ with $6.6 \%$ (Statistica, 2021). Most Twitter users are male, with a percentage up to $70.4 \%$, compared to female users with only $29.7 \%$ (Iqbal, 2021). This number is considered significant with an uneven demographic user capacity. Hence, it is not surprising that Twitter's profit in 2020 was reported to have touched the 1.1 million dollar mark.

Daily users Twitter reached 119 million with 500 million tweets every day. Besides the United States, the other three countries with the most Twitter users are Japan (50.9 million), India (17.5 million), and the United Kingdom (16.45 million) (TwitterIR, 2021). In order to ensure the users' convenience, Twitter is constantly making improvements by adding valuable and fun features for its users. One of the added features in 2021 is space, where users can broadcast similar to radio, and the other users can join the space. The broadcast can be accessed 
freely, even if each user does not follow the other. This feature makes the realm of interaction on Twitter broader but again remains anonymous.

\section{Derek Parfit's personal-identity theory}

Parfit highlights the human tendency always to prioritize their identity. Parfit's theory was once contradicted with body and mind continuity theory. Parfit mentioned that humans have two elements of self: material properties and immaterial properties. According to Parfit, survival is more important than finding identity. In other words, Parfit tries to say that personal identity is not crucial because of how illusory someone's identity is (Putra et al., 2020).

Parfit stated that humans tend to be more open when they do not know each other's identities. In using social media, there will be growing a free sense of individual whenever interacts anonymously, so an urge to do anything freely appears. The untied and safe senses that occur when using Twitter then motivate someone to behave freely, including triggering positive and negative impacts at the same time.

The most noticeable impact of anonymity on Twitter is the rate of cyberbullying that can be said relatively high. Research by one of the universities in America in 2012 reported that at least 15.000 tweets contain bullying on Twitter daily. Online bullying behavior rife is not solely influenced by the bully's desire but also the existence of the wide-open space. The belief that all actions are carried out behind anonymous accounts makes it easier for someone to behave arbitrarily without worrying about their identity.

Based on the previous explanation, appears a question, "what is the effect of anonymity towards Twitter users' behavior?" Therefore, this research will try to dig into the phenomena and find out their impact based on the philosophical perspective of Derek Parfit's personal identity theory. 


\section{METHOD}

This research uses mix-methods (quantitative and qualitative). The quantitative approach is used to collect the massive data. Meanwhile, a qualitative approach is used to obtain more profound and detailed data. The quantitative data was collected through an esurvey, then strengthened by the interviews with respondents who matched the research criteria.

The population of this research is 50 adolescents with criteria own and use of anonymous accounts on Twitter. The research's sample is the users with a minimum age of 18 years old, and it was picked randomly from the population. The questionnaire was validated based on a significance correlation test of 0.05 with a reliability coefficient of 0.78 . The questions in the questionnaire are based on Derek Parfit's personal-identity theory that the researcher already developed.

The survey contains twelve common questions which can be answered with scala Likert 1-5. The survey was conducted privately by sharing the link to the respondent through Twitter's direct message. The survey was then narrowed down from filling in the quantitative data by selecting respondents randomly as a sample of the population to be interviewed. The type of questions asked is a development of the questions contained in the questionnaire and can be answered with a more detailed description. The data obtained is then processed and analyzed to show the results before being presented in tables and descriptions.

\section{RESULT}

\section{Respondents' Demographic Table}

Table 1. Respondents' Demographic Characteristics

\begin{tabular}{lll}
\hline Variable & Number of & Percentage \\
\hline
\end{tabular}




\begin{tabular}{|c|c|c|}
\hline & Responden & \\
\hline \multicolumn{3}{|l|}{ Gender } \\
\hline Men & 13 & $24 \%$ \\
\hline Women & 37 & $74 \%$ \\
\hline \multicolumn{3}{|l|}{ Age } \\
\hline 18 & 12 & $24 \%$ \\
\hline 19 & 10 & $20 \%$ \\
\hline 20 & 15 & $30 \%$ \\
\hline 21 & 8 & $16 \%$ \\
\hline 22 & 5 & $10 \%$ \\
\hline
\end{tabular}

The sample in the population shows a contrast, where more than $50 \%$ of the sampling is female. The sample's age range is mainly dominated by the age of 20 years with a percentage of $30 \%$. The highest age in the sampling is 22 years, with the smallest percentage of $10 \%$.

Based on the study results, most Twitter users have anonymous accounts to maintain privacy and express themselves freely. This is proven by the fact that $68 \%$ of 50 respondents have anonymous accounts as a means of expressing themselves. This shows that most Twitter users are more comfortable hiding their identities when communicating or exchanging opinions.

Table 3. Percentage of respondents who use an anonymous account

\begin{tabular}{lcc|}
\hline \multicolumn{1}{|c}{ Anonymous Account Usage } & $\begin{array}{c}\text { Number of } \\
\text { Respondents }\end{array}$ & Percentage \\
\hline $\begin{array}{l}\text { Currently/often use an } \\
\text { anonymous account }\end{array}$ & 34 & $68 \%$ \\
$\begin{array}{l}\text { Have/rarely use an anonymous } \\
\text { account }\end{array}$ & 8 & $16 \%$ \\
$\begin{array}{l}\text { Never use an anonymous } \\
\text { account }\end{array}$ & 8 & $16 \%$ \\
\hline
\end{tabular}


Although many advantageous effects result from anonymity on Twitter, such as communication and freedom of expression for all people, many harmful impacts can be caused by anonymity in social media. From the research that has been done, the number of anonymity activities on social media can trigger cyberbullying because the freedom gained by the anonymous perpetrator makes them feel comfortable about their hidden identity. Therefore, it is necessary to educate the public to increase awareness of the importance of being careful in using social media and maintaining etiquette in voicing opinions.

As stated in Article 28 of the 1945 Constitution, Law (UU) No. 39 of 1999 concerning Human Rights (articles 14 and 32), all Indonesian people have the right to express themselves both verbally and through social media. With the development of the times, it is now easier for each individual to voice their opinion. Various social media provide a considerable space for everyone to publish their minds, such as Twitter, Instagram, and Facebook.

Social media such as Twitter has made it easier for us to access various available sources of information. Much helpful information for numerous groups is shared and enjoyed every day. Communication from individuals from all parts of the world can be done quickly, exchanging opinions can be done comfortably. However, there is a negative side generated by the freedom that is too much behind all that. False information, insults, swearing, blasphemy, gossip, and even slander are spread on the other side of the social media used by our generation. These actions are usually carried out by individuals who hide behind anonymous accounts so that the perpetrators can comfortably carry out nefarious activities that can harm many people.

Table 3. Percentage of respondents' convenience in expressing themselves with anonymous accounts

\begin{tabular}{ccc}
$\begin{array}{c}\text { Level of } \\
\text { Convenience }\end{array}$ & $\begin{array}{c}\text { Number of } \\
\text { Respondents }\end{array}$ & Percentages \\
\hline
\end{tabular}




\begin{tabular}{ccc}
\hline $\begin{array}{c}\text { Comfortable/conve } \\
\text { nience }\end{array}$ & 33 & $66 \%$ \\
Normal & 10 & $20 \%$ \\
Not comfortable & 7 & $14 \%$ \\
\hline
\end{tabular}

Based on the interview result with three respondents, the data showed that most Twitter users who use anonymous accounts are more comfortable expressing themselves using anonymous accounts rather than in their real accounts or real world. The three respondents admitted that they felt freer to express their opinions and communicate more about any interest or topic when no one from the real world knew their real identity.

"Yes. I feel that I'm more comfortable spending time with friends on social media than my real-world friends." (Informant I)

"Very much. Moreover, maybe because I have a Twitter account specifically for Korea that does not expose my real life so much, I can act more freely. In there, I have lots of friends, and I feel closer to them, not like in the real world (where I am not that close with people)." (Informant II)

"Of course, especially if there is a problem, I will always share it with my mutuals (on Twitter)." (Informant III)

Because they feel more comfortable hiding behind anonymous accounts, it is known that the sources even have different personalities in the virtual world than in the real world. 
"Yeah, I like to think that way. My personality in the real world is chatty and likes to overshare, I would rather do it on another account, okay? In this account (non-private account), I let myself be the person who does not act a lot and does not cause problems." (Informant I)

"I have two Twitter accounts; one for my real life, one anonymous. I think (the two) are different. The anonymous (account) is more outspoken because I do not know (other users) and do not get into trouble with other people. In real life, I am more introverted." (Informant II)

"Pretty different, really. On Twitter, I am more chatty, and it is easier to express my emotions." (Informant III)

From the interviews, it is known that the informants chose to create an anonymous account so that their friends in the real world do not judge them when they express themselves on the account.

"I am afraid that my Twitter account will be known by my friends or people I know in the real world. I like to read LGBT stuff." (Informant I)

"I am free to make any tweets because my real friends in the real world rarely know (my account)." (Informant II)

"I do not want my friends to know my true nature." (Informant III)

\section{DISCUSSION}


Results of the study prove that most Twitter users are more comfortable using anonymous profiles to communicate in the application. Using an anonymous account is often caused by an individual's distrust of themself and others, so they feel that it is better to hide behind an anonymous account and create another personality behind it. This is related to the personal identity theory of Derek Parfit. Parfit assumes that a unique entity, such as oneself, does not describe or unify one's experiences and dispositions over time, so self-identity is not essential for survival.

This theory is proven by the results of research that illustrate that most Twitter social media users feel more comfortable and open with themselves when they do not show their identity or are commonly referred to as anonymous. According to D. M. Pedersen (1997), there are three reasons why an individual performs anonymity, namely recovery, catharsis, and autonomy. Recovery is an update that involves active contemplation of the situation at hand to produce relaxation. Meanwhile, catharsis is an unavoidable expression of thoughts and feelings to others. The last is autonomy, which involves experimenting with new behaviors without fear of social consequences. For these reasons, it is not surprising that anonymous accounts in Indonesia are increasing day by day.

Various kinds of impacts, positive and negative, arise as anonymity activities increase. Things like individuals who can comfortably express themselves and share opinions about all the problems in the world, information obtained from various groups in all parts of the world, friendships that arise from unlimited freedom are some of the positive effects of anonymity. On the other hand, the negative impacts that occur are no less numerous. Deindividualization or loss of self-awareness, freedom to spread false information, increased cyberbullying because they are not afraid of social consequences behind anonymous accounts. 
The faster the development of the internet, it can be seen that it also increases the value and benefits of the internet itself. Therefore, it is necessary to conduct counseling to raise awareness of anonymity's positive and negative impacts so that it will not be misused and carried out optimally. The value and benefits obtained also can be maximized.

\section{CONCLUSION}

The research shows that more than $50 \%$ of the respondents reasoned that using an anonymous Twitter account brings the feel of comfort, safety, and freedom. This data is supported by the interview result, which shows that the most common reason for making an anonymous account is the willingness to express oneself freely without someone from real life finding out. This research gets $66 \%$ of the sample who feel more comfortable using Twitter anonymously. This result is linear with Derek Parfit's theory that someone's identity is not the most important thing. In the personal identity theory, Derek Parfit assumed that not knowing each other identities when interacting will increase the tendency to be more flexible. However, this anonymity is also known to bring along another impact, such as increasing the level of bullying on Twitter. To deal with this problem, further awareness and assistance in social media are needed to utilize existing social media more efficiently.

\section{REFERENCES}

Abraham, Firda. (2014). Pemanfaatan Twitter Sebagai Media Komunikasi Massa. Jurnal Penelitian Pers dan Komunikasi Pembangunan, 18(1), 67-80. https://doi.org/10.46426/jp2kp.v18i1.11

Afriluyanto, T. R. (2018). Fenomena Remaja Menggunakan Media Sosial dalam Membentuk Identitas. KOMUNIKA: Jurnal Dakwah Dan Komunikasi, 11(2), 184-197. https://doi.org/10.24090/komunika.v11i2.1365

Amry, Helva dan Mario Pratama. (2021). Pengaruh Anonimitas Terhadap Cyberbullying pada Penggemar K-POP Twitter. Jurnal Ilmu Pengetahuan Sosial, 8(1), 262-270. http://dx.doi.org/10.31604/jips.v8i1.2021.262-270

Arifin, H. S., Taty H., Weny W. (2017). Freedom of Expression di Media Sosial bagi Remaja Secara Kreatif dan Bertanggung Jawab bagi Siswa SMA Al-Ma'soem Rancaekek dan 
SMA Muhammadiyah Pangandaran. Jurnal Pengabdian Kepada Masyarakat, 1(5), 332337.

Christianto, Hwian. (2020). Penggunaan Media Internet dalam Pemenuhan Hak Atas Pendidikan di Masa Pandemi COVID-19 Perspektif Hak Asasi Manusia dan Hukum Pidana. Jurnal HAM, 11(2), 239-253. http://dx.doi.org/10.30641/ham.2020.11.239-253

Harmaningsih, D., Susi Y., Wijayanti. (2021). Anonimitas Netizen di Media Sosial. Jurnal IKRAITH-HUMANIORA, 5(3), 76-85.

Hasfi, N., Sunyoto U., Hedi P. S. (2017). Anonimitas di Media Sosial: Sarana Kebebasan Berekspresi atau Patologi Demokrasi?. Jurnal Ilmu Komunikasi, 15(1), 29-38.

Irawan, A. W., Aan Y., Dwi A., Reagan D., et al. (2020). Laporan Survei Internet APJII 20192020 (Q2). Indonesia Survey Center.

Irwansyah dan Ari Wicaksono. (2017). Fenomena Deindividualisasi dalam Akun Anonim Berita Gosip Selebriti di Media Sosial Instagram. Profetik Jurnal Komunikasi, 10(2), 3445.

Kemp, S. (2021). Digital 2021: Global Overview Report. Datareportal. Digital 2021: Global Overview Report - DataReportal - Global Digital Insights. Diakses 25 November 2021.

Marsinun, Rahmiwati dan Dody Riswanto. (2020). Perilaku Cyberbullying Remaja di Media Sosial. Jurnal Magister Psikologi UMA, 12(2), 98-111. DOI: http://doi.org/10.31289/analitika.v12i2.3704

Mukkhoyyaroh, Tatik. (2020). Anonimitas dan Deindividuasi pada Remaja Pengguna Sosial $\begin{array}{llll}\text { Media. Jurnal Penelitian } & \text { Psikolog, }\end{array}$ DOI:http://doi.org/10.29080/jpp.v11i1.354

Mutma, F. S. (2019). Deskripsi Pemahaman Cyberbullying di Media Sosial pada Mahasiswa. Jurnal Komunikasi, 13(2), 155-182. DOI: https://doi.org/10.21107/ilkom.v13i2.5928

Nesi, J. (2020). Understanding the Impact of Social Media on Youth Mental Health. 81(2), $116-121$.

Nurhadi, Z. F. (2017). Model Komunikasi Sosial Remaja Melalui Media Sosial. Jurnal ASPIKOM, 3(3), 539-549.

Putra, A. W., Mukhtasar, M., Arqom, K. (2020). Krisis Identitas dalam Perspektif Personal Identity Derek Parfit. http://etd.repository.ugm.ac.id/

Roser, M., Hannah R., Esteban O. (2015). Internet. Our World in Data. https://ourworldindata.org/internet. Diakses 27 November 2021

Saptiawan, I. H. (2018). Dari Anonim Kembali ke Anonim. Jurnal Pendidikan Bahasa dan Sastra Indonesia., 1(2), 80-88.

Sari, R. N. dan Suryanto. (2016). Kecerdasan Emosi, Anonimitas, dan Cyberbullying (Bully Dunia Maya). Jurnal Psikologi Indonesia, 5(1), 48-61. https://doi.org/10.30996/persona.v5i01.741 
Sasmita, R. S. (2020). Pemanfaatan Internet Sebagai Sumber Belajar. Jurnal Pendidikan dan Konseling, 2(1), 99-103.

Şimşek, N., Şahin, D., \& Evli, M. (2019). Internet Addiction, Cyberbullying, and Victimization Relationship in Adolescents: A Sample from Turkey. Journal of Addictions Nursing, 30(3), 201-210. https://doi.org/10.1097/JAN.0000000000000296

Statista Research Department. (2021). Distribution of Twitter users worldwide as of April 2021, by age group. https://www.statista.com/statistics/283119/age-distribution-of-globaltwitter-users/. Diakses 25 November 2021. 